\title{
Hallucinogen-Like Action of the Novel Designer Drug 25I-NBOMe and Its Effect on Cortical Neurotransmitters in Rats
}

\author{
Monika Herian $^{1} \cdot$ Adam Wojtas $^{1} \cdot$ Katarzyna Kamińska $^{1} \cdot$ Paweł Świt $^{1} \cdot$ Anna Wach $^{1} \cdot$ Krystyna Gołembiowska $^{1}$
}

Received: 15 October 2018 / Revised: 20 March 2019 / Accepted: 26 March 2019 / Published online: 15 April 2019

(C) The Author(s) 2019

\begin{abstract}
NBOMes are N-benzylmethoxy derivatives of the 2C family hallucinogens. 4-Iodo-2,5-dimethoxy-N-(2methoxybenzyl)phenethylamine (25I-NBOMe) is one of the commonly used illicit drugs. It exhibits high binding affinity for 5$\mathrm{HT}_{2 \mathrm{~A} / \mathrm{C}}$ and 5- $\mathrm{HT}_{1 \mathrm{~A}}$ serotonin receptors. Activation of 5- $\mathrm{HT}_{2 \mathrm{~A}}$ receptor induces head-twitch response (HTR) in rodents, a behavioral marker of hallucinogen effect in humans. There is not much data on neurochemical properties of NBOMes. Therefore, we aimed to investigate the effect of 25I-NBOMe on extracellular level of dopamine (DA), serotonin (5-HT), and glutamate (GLU) in the rat frontal cortex, tissue contents of monoamines, and hallucinogenic activity in rats. The extracellular levels of DA, 5-HT, and GLU were studied using microdialysis in freely moving animals. The tissue contents of DA, 5-HT and their metabolites 3,4dihydroxyphenylacetic acid (DOPAC), homovanillic acid (HVA), and 5-hydroxyindoleacetic acid (5-HIAA) were determined in the rat frontal cortex. We also tested a drug-elicited HTR. 25I-NBOMe at doses 1, 3, and $10 \mathrm{mg} / \mathrm{kg}$ (sc) increased extracellular DA, 5HT, and GLU levels, enhanced tissue content of 5-HT and 5-HIAA, but did not affect tissue level of DA and its metabolites. The compound exhibited an inverted $U$-shaped dose-response curve with respect to the effect on extracellular DA and 5-HT levels, but a $U$-shaped dose-response curve was observed for its effect on GLU release and HTR. The data from our study suggest that hallucinogenic activity of 25I-NBOMe seems to be related with the increase in extracellular GLU level-mediated via cortical $5-\mathrm{HT}_{2 \mathrm{~A}}$ receptors. The influence of $25 \mathrm{I}-\mathrm{NBOMe}$ on $5-\mathrm{HT}_{2 \mathrm{C}}$ and $5-\mathrm{HT}_{1 \mathrm{~A}}$ receptors may modulate its effect on neurotransmitters and $\mathrm{HTR}$.
\end{abstract}

Keywords $25 \mathrm{I}-\mathrm{NBOMe} \cdot$ Neurotransmitter release $\cdot$ Dopamine $\cdot$ Serotonin $\cdot$ Glutamate $\cdot$ Head-twitch response

\section{Introduction}

New psychoactive substances (NPS) are substitutes of wellknown drugs with hallucinogenic effect on the central nervous system (CNS). The number of NPS that appear on the illicit drug market each year still remains high. According to EMCDDA (European Monitoring Centre for Drugs and Drug Addiction) by the end of 2017, above 670 new psychoactive substances have been identified and monitored. As for 2017, 51 new drugs have emerged, coming from many different classes of substances, e.g., synthetic cathinones,

Electronic supplementary material The online version of this article (https://doi.org/10.1007/s12640-019-00033-x) contains supplementary material, which is available to authorized users.

Krystyna Gołembiowska

nfgolemb@cyf-kr.edu.pl

1 Department of Pharmacology, Institute of Pharmacology, Polish Academy of Sciences, 12 Smętna, 31-343 Kraków, Poland cannabinoids, or hallucinogens (EMCDDA 2018). These numbers show that although NPS have been marked as a target for legal restrictions in the USA and Europe, they still pose a threat for public health.

Hallucinogenic compounds have been known to mankind for centuries along with ethanol they might be one of the oldest known psychoactive substances (Nichols 2016; Schultes et al. 1998). They produce a variety of effects after administration, mostly revolving around visual and auditory hallucinations and mental distortions (Nichols 2004; UNODC 2013) and their use leads to a rapid development of tolerance, and cross-tolerance phenomenon (Abramson et al. 1956; Angrist et al. 1974; Wolbach et al. 1962). Hallucinogens can be divided into two main groups, namely indoleamines and phenylalkylamines, the latter can be also further broken into phenethylamines (such as mescaline, $2 \mathrm{C}-\mathrm{X}$ compounds) and phenylisopropylamines (i.e., DOM) (Halberstadt 2017; Nichols 2012). Indoleamines include ergolines, rigid structural analogues related to LSD, and simple tryptamines, such as DMT or 5-methoxy-DMT (Nichols 2004, 2012; Halberstadt 
2015). Phenylalkylamine hallucinogens are selective for 5$\mathrm{HT}_{2 \mathrm{~A}}, 5-\mathrm{HT}_{2 \mathrm{~B}}$, and $5-\mathrm{HT}_{2 \mathrm{C}}$ receptors, and some of these compounds display over 1000 -fold selectivity for agonist-labeled 5- $\mathrm{HT}_{2}$ receptors versus $5-\mathrm{HT}_{1}$ sites (Pierce and Peroutka 1989). The tryptamines, by contrast, bind non-selectively to 5-HT receptors and are substrates for the 5-HT transporter (SERT) (Nagai et al. 2007; Cozzi et al. 2009; Halberstadt and Geyer 2011). However, tryptamines are more potent at $5-\mathrm{HT}_{1 \mathrm{~A}}$ and $5-\mathrm{HT}_{2 \mathrm{~A}}$ receptors by several orders of magnitude as compared to SERT (Cozzi et al. 2009; Halberstadt and Geyer 2011; Nagai et al. 2007). The addition of $N$-benzyl group to phenethylamines potently increased their activity, and $N$-benzylphenethylamines are now a new class of hallucinogens (Braden et al. 2006).

Activation of $5-\mathrm{HT}_{2 \mathrm{~A}}$ receptor induces head-twitch response (HTR) in rodents which is a behavioral marker of hallucinogenic effect in humans. Serotonergic hallucinogens induce HTR in mice and rats also referred to as a wet dog shakes (WDS). The fact that DOI can provoke HTR in 5$\mathrm{HT}_{2 \mathrm{C}}$ knockout mice but not in 5- $\mathrm{HT}_{2 \mathrm{~A}}$ knockouts strongly suggests the $5-\mathrm{HT}_{2 \mathrm{~A}}$ receptor is responsible for mediating HTR (Canal et al. 2010). These findings indicate that 5$\mathrm{HT}_{2 \mathrm{C}}$ activation inhibits HTR. On the other hand, the 5$\mathrm{HT}_{2 \mathrm{~A}}$ and $5-\mathrm{HT}_{1 \mathrm{~A}}$ receptors make positive and negative contribution, respectively, to the induction of HTR by tryptamine hallucinogens (Klein et al. 2018).

The enhanced release of glutamate is a common mechanism in the action of hallucinogens. In vivo microdialysis, experiments showed that systemic administration of DOI, 5MeO-DIPT, and LSD significantly increased extracellular levels of glutamate in the rat frontal cortex (Muschamp et al. 2004; Noworyta-Sokołowska et al. 2016, 2019; Scruggs et al. 2003). The increase in glutamate elicited by intracortical DOI was blocked by the selective $5-\mathrm{HT}_{2 \mathrm{~A}}$ receptor antagonist MDL 100,907 (Scruggs et al. 2003).

Although most of behavioral effects of hallucinogens are due to activation of 5- $\mathrm{HT}_{2 \mathrm{~A}}$ receptors, the higher doses of some hallucinogens may activate also $5-\mathrm{HT}_{2 \mathrm{C}}$ receptors, which functionally oppose the effects of $5-\mathrm{HT}_{2 \mathrm{~A}}$ receptors. For instance, low doses of DOI increase locomotor activity in mice, whereas higher doses attenuate it (Halberstadt et al. 2009). The same phenomena can be observed in the mouse HTR (Fantegrossi et al. 2010).

It was hypothesized that the suppressant effect of tryptamine psychedelics and LSD on raphe cell firing results from stimulation of somatodendritic 5- $\mathrm{HT}_{1 \mathrm{~A}}$ autoreceptors (Aghajanian and Haigler 1975). However, in subsequent studies, phenethylamine psychedelics which lack $5-\mathrm{HT}_{1 \mathrm{~A}}$ receptor agonist activity also suppressed raphe cells firing, but only when administered systematically but not directly into the raphe cells (Haigler and Aghajanian 1973). This suppressant effect by phenethylamine psychedelics is thought to occur through an indirect GABA-mediated mechanism (Martín-Ruiz et al. 2001).
A number of reports provide evidence for direct and indirect modulation of VTA dopaminergic neurons through activation of 5- $\mathrm{HT}_{2 \mathrm{~A}}$ receptors (Cornea-Hébert et al. 1999). 5$\mathrm{HT}_{2 \mathrm{~A}}$ receptors may directly affect local release of DA, but some $5-\mathrm{HT}_{2 \mathrm{~A}}$ receptors can modulate VTA non-dopaminergic cells, perhaps GABAergic interneurons in VTA (Nocjar et al. 2002; Pehek et al. 2001).

NBOMes are N-benzylmethoxy derivatives of the $2 \mathrm{C}$ family of hallucinogens which are substituted phenethylamines. The presence of an $N$-benzyl group increased $5-\mathrm{HT}_{2 \mathrm{~A}}$ affinity of these drugs (Nichols 2016). The most commonly used NBOMe substances include 4-iodo-2,5-dimethoxy-N-(2methoxybenzyl)phenethylamine, 4-bromo-2,5-dimethoxy$\mathrm{N}$-(2-methoxybenzyl)phenethylamine, and 4-chloro-2,5dimethoxy-N-(2-methoxybenzyl)phenethylamine (25I$\mathrm{NBOMe}, 25 \mathrm{~B}-\mathrm{NBOMe}$ and 25C-NBOMe, respectively) (Kyriakou et al. 2015). The NBOMes became available to drug users when they first appeared on the drug market in 2010, with 25I-NBOMe emerging as the earliest (Halberstadt 2017; Poklis et al. 2015; Zuba et al. 2013). NBOMes usually are sold on a blotter paper or in powder under various names: "Smiles," "N-Bombs," "Solaris," "Cimbi," or "25I," "25B," and "25C" (indicating their shortened chemical name). Decorated colorful papers infused with the drug are often distributed as lysergic acid diethylamide (LSD) due to a similar psychological and somatic effects (so-called "legal LSD") (Suzuki et al. 2015). They are administered either nasally or orally (either by swallowing or sublingually) in submiligram doses (Poklis et al. 2015). The duration of action varies depending on the route of administration (Halberstadt and Geyer 2014). The effects of ingestion usually reflect the activation of serotonergic and adrenergic pathways and include severe visual and auditory hallucinations, agitation, aggressiveness, sweating, and psychotic/paranoid behavior (Al-Imam and Abdul Majeed 2017; Gee et al. 2016; Hill and Thomas 2011; Nikolaou et al. 2015). NBOMes have been associated with severe non-fatal toxicity and fatalities (Baumann et al. 2017; Halberstadt 2017; Kyriakou et al. 2015; Rose et al. 2013; Shanks et al. 2015; Walterscheid et al. 2014). Mild effects of NBOMe ingestion include tachycardia, hypertension, clonus, hallucinations, and panic attacks. In the case of heavy poisoning, seizures, renal failure, rhabdomyolysis, hyperthermia, and metabolic acidosis may occur (Andreasen et al. 2015; Kueppers and Cooke 2015). Similarly to other classes of hallucinogens, NBOMes act as $5-\mathrm{HT}_{2 \mathrm{~A}}$ receptor agonists and are relatively non-selective for $5-\mathrm{HT}_{2 \mathrm{~A}}$ vs. $5-\mathrm{HT}_{2 \mathrm{C}}$ sites (Nichols et al. 2015). 25I-NBOMe exhibits high in vitro-binding affinity for $5-\mathrm{HT}_{1 \mathrm{~A}}\left(K_{i}=1800 \mathrm{nM}\right), 5-\mathrm{HT}_{2 \mathrm{~A}}\left(K_{i}=0.6 \mathrm{nM}\right)$, and 5$\mathrm{HT}_{2 \mathrm{C}}$ receptors $\left(K_{i}=4.6 \mathrm{nM}\right)$ (Rickli et al. 2015). 25INBOMe shows high affinity for adrenergic $\alpha_{1 \mathrm{~A}}\left(K_{i}=\right.$ $370 \mathrm{nM})$ and $\alpha_{2 \mathrm{~A}}\left(K_{i}=320 \mathrm{nM}\right)$ receptors. Furthermore, binding affinity for $D_{1}, D_{2}$, and $D_{3}$ receptors is 6700,900 , and $2100 \mathrm{nM}$, respectively (Rickli et al. 2015). 
25I-NBOMe was potent in decreasing locomotor activity in mice (Gatch et al. 2017; Halberstadt 2017). Another study performed on mice showed no effects on locomotor activity after intraperitoneal administration of 25I-NBOMe (0.03$3 \mathrm{mg} / \mathrm{kg}$ ). Instead, its subcutaneous administration at $0.1 \mathrm{mg} / \mathrm{kg}$ increased locomotor activity, while a dose of $3 \mathrm{mg} / \mathrm{kg}$ reduced this activity (Halberstadt 2017). Administration of NBOMe evoked HTR in C57BL/6J mice (Halberstadt and Geyer 2014) and in rats (Elmore et al. 2018). It is believed that NBOMes' hallucinogenic properties result from the activation of the cortical $5-\mathrm{HT}_{2 \mathrm{~A}}$ receptors (Aghajanian and Marek 1997; Glennon et al. 1984; Sipes and Geyer 1995; Wing et al. 1990).

So far, there is not much neurochemical data about NBOMe compounds and their pharmacological properties. Therefore, the aim of this study was to investigate the effects of 25I-NBOMe on extracellular levels of dopamine (DA), serotonin (5-HT), and glutamate (GLU) in the frontal cortex, tissue content of neurotransmitters, and hallucinogenic activity of this compound in rats.

\section{Materials and Methods}

\section{Animals}

Male Wistar-Han rats (Charles River, Sulzfeld, Germany) weighting from 280 to $350 \mathrm{~g}$ were used in all performed experiments. Animals were initially acclimatized and housed (5 per cage) in environmentally controlled rooms under 12-h light/dark cycle (the light was switched on at 6 a.m.) at a temperature of $23 \pm 1{ }^{\circ} \mathrm{C}$ and humidity of $55 \pm 10 \%$. Rats had free access to typical laboratory food and tap water (VRF 1, Special Diets Services, Witham, UK), enriched environment was not applied. The studies strictly conformed to European regulations for animal experimentation (EU Directive 2010/63/EU on the protection of animals used for scientific purposes). The experimental protocols were approved by the Local Ethics Commission for Experimentation on Animals (permit nos. 186 and 189/2017). This article does not contain any studies with human participants by any of the authors.

\section{Drugs and Reagents}

2-(4-Iodo-2,5-dimethoxyphenyl)-N-(2-methoxybenzyl)ethanamine (25I-NBOMe) was purchased from Cayman Chemical Company (Michigan, USA). All necessary chemicals for analysis with the use of high-performance liquid chromatography (HPLC) were obtained from Merck (Warszawa, Poland) and were of the highest purity. Ophthalaldehyde (OPA) obtained from Sigma-Aldrich was used for derivatization of glutamate to electroactive compound.

\section{Drug Administration}

During the experiment animals received subcutaneous (sc) single injections of 25I-NBOMe dissolved in $0.9 \% \mathrm{NaCl}$ at four doses of $0.3,1,3$, and $10 \mathrm{mg} / \mathrm{kg}$. The control group was administered $0.9 \% \mathrm{NaCl}$ solution in the same way.

\section{Brain Microdialysis}

Ketamine and xylazine solutions at doses of 75 and $10 \mathrm{mg} / \mathrm{kg}$, respectively, were used to anesthetize animals. In the next step, animals were placed in the stereotaxic device (David Kopf Instruments, Tujunga, USA). The skin was peeled away from the skull, holes were drilled in the bone, and microdialysis probes (MAB 4.15.3 Cu, AgnTho's AB, Lindingö, Sweden) were implanted into the rat frontal cortex (FCx) using the following coordinates (mm): $\mathrm{AP},+2.7 ; \mathrm{L},+0.8 ; \mathrm{V}$, -6.5 , from the dura (Paxinos and Watson 1998). The number of animals for each treatment group was six. On the next day, probe inlets were connected to a syringe pump (BAS, West Lafayette, IN, USA), which delivered artificial cerebrospinal fluid composed of (mM): 147, $\mathrm{NaCl} ; 2.7, \mathrm{KCl} ; 1.0, \mathrm{MgCl}_{2}$; $1.2, \mathrm{CaCl}_{2}, \mathrm{pH} 7.4$ at a flow rate of $2 \mu \mathrm{L} / \mathrm{min}$. After a $2-\mathrm{h}$ washout period, five basal dialysate samples were collected every $20 \mathrm{~min}$, then animals were injected subcutaneously with 25I-NBOMe as indicated in the figure captions and fraction collection continued for $240 \mathrm{~min}$. At the end of the experiment, the rats were sacrificed and their brains were histologically verified for the proper probe placement.

\section{Extracellular Concentration of DA, 5-HT, and Glutamate}

The DA and 5-HT concentrations in dialysate fractions were analyzed by HPLC with electrochemical detection. Chromatography was performed using an Ultimate 3000 System (Dionex, Sunnyvale, CA, USA), electrochemical detector Coulochem III (model 5300; ESA, Chelmsford, MA, USA) with a 5020 guard cell, a 5040 amperometric cell, and a Hypersil Gold C18 analytical column $(3 \mu \mathrm{m}, 100 \times 3 \mathrm{~mm}$; Thermo Fischer Scientific, Waltham, MA, USA). The mobile phase was composed of $0.1 \mathrm{M}$ potassium phosphate buffer adjusted to $\mathrm{pH} 3.8,0.5 \mathrm{mM} \mathrm{Na}{ }_{2}$ EDTA, $100 \mathrm{mg} / \mathrm{L} \mathrm{1-}$ octanesulfonic acid sodium salt, and $2 \%$ methanol. The flow rate during analysis was set at $0.6 \mathrm{~mL} / \mathrm{min}$. The applied potential of a guard cell was $600 \mathrm{mV}$, while that of amperometric cell was $300 \mathrm{mV}$ with a sensitivity set at $10 \mathrm{nA} / \mathrm{V}$. The chromatographic data were processed by Chromeleon v. 6.80 (Dionex) software package run on a personal computer. The limit of detection of DA and 5-HT in dialysates was $0.002 \mathrm{pg} /$ $10 \mu \mathrm{L}$ for DA and $0.01 \mathrm{pg} / 10 \mu \mathrm{L}$ for 5 -HT.

Glutamate levels in the extracellular fluids were measured electrochemically after derivatization with OPA/sulfite 
reagent to form isoindole-sulfonate derivative (Rowley et al. 1995). Chromatography was performed using an Ultimate 3000 pump (Dionex), LC-4B amperometric detector with a cross-flow detector cell (BAS), and a HR-80 column $(3 \mu \mathrm{m}, 80 \times 4.6 \mathrm{~mm}$; ESA Inc., Chelmsford, MA, USA). The mobile phase consisted of $100 \mathrm{mM}$ monosodium orthophosphate at $\mathrm{pH} 4.6$ and $4 \%$ methanol. The flow rate was $1 \mathrm{~mL} / \mathrm{min}$, and the applied potential of a 3-mm glassy carbon electrode was set at $+600 \mathrm{mV}$ at a sensitivity of $5 \mathrm{nA} /$ $\mathrm{V}$. Glutamate-derivative peak was compared with the respective standard, and the data were processed using Chromax 2005 (Pol-Lab, Warszawa, Poland) software on a personal computer. The limit of detection of glutamate in dialysates was $0.03 \mathrm{ng} / 10 \mu \mathrm{L}$.

\section{The Measurement of Tissue Content of DA, 5-HT, and their Metabolites}

Animals were sacrificed by decapitation 45 min after subcutaneous drug administration. Brains were removed and the frontal cortices were dissected in anatomical borders. The tissue levels of DA, 5-HT, 3,4-dihydroxyphenylacetic acid (DOPAC), homovanillic acid (HVA), and 5hydroxyindoleacetic acid (5-HIAA) were measured using HPLC with electrochemical detection. Tissue samples of frontal cortices were homogenized in an ice-cold $0.1 \mathrm{M}$ $\mathrm{HClO}_{4}$, and were centrifuged at $10,000 \times \mathrm{g}$ for $10 \mathrm{~min}$ at $4{ }^{\circ} \mathrm{C}$ ). The obtained supernatants were filtered through $0.22 \mu \mathrm{m}$ Ultrafree Centrifugal Filters (Merck Millipore Ltd., Ireland) and 3-5 $\mu \mathrm{L}$ of samples were injected into an HPLC system. The chromatographic system consisted of an UltiMate 3000 pump (Thermo Scientific, USA), an LC-4C amperometric detector with a cross-flow detector cell (BAS, IN, USA), and a HR-80 analytical column $(3 \mu \mathrm{m}, 80 \times$ $4.6 \mathrm{~mm}$, ESA, Inc., USA). The mobile phase consisted of $0.1 \mathrm{M} \mathrm{KH}_{2} \mathrm{PO}_{4}, 0.5 \mathrm{mM}$ EDTA, $95 \mathrm{mg} / \mathrm{L}$ sodium 1octanesulfonate, and $4 \%$ methanol, adjusted to $\mathrm{pH}=3.8$ with $85 \% \mathrm{H}_{3} \mathrm{PO}_{4}$. The flow rate was $1 \mathrm{~mL} / \mathrm{min}$. The potential of a 3-mm glassy carbon electrode was set at $+700 \mathrm{mV}$ with sensitivity of $5 \mathrm{nA} / \mathrm{V}$. The temperature of the column was maintained at $30^{\circ} \mathrm{C}$. The obtained data were collected and processed by Chromax 2007 software (Pol-Lab, Warszawa, Poland).

\section{Head-Twitch Test}

Head-twitch test was carried out during microdialysis experiment. Immediately after 25I-NBOMe administration, animals placed in microdialysis cylinders were observed by experimenters and the number of head twitches was counted for a period of $240 \mathrm{~min}$.

\section{Data Analysis}

Drug effects on DA, 5-HT, and glutamate release in the frontal cortex were analyzed with repeated measures ANOVA followed by Tukey's post hoc test. All obtained data were presented as a percent of the basal level assumed to be $100 \%$. The tissue content of neurotransmitters and HTR were tested using one-way ANOVA followed by Tukey's post hoc test. The differences were considered significant if $P$ value was smaller than 0.05 . All statistical analyses were carried out using STATISTICA v.10 StatSoft Inc. 1984-2011 (San Francisco, CA, USA).

\section{Results}

\section{The Effect of 25I-NBOMe Administration on the Extracellular Levels of DA, 5-HT, and Glutamate in the Rat Frontal Cortex}

25I-NBOMe significantly $(P<0.0002)$ increased extracellular DA levels in the rat frontal cortex. The dose of $3 \mathrm{mg} / \mathrm{kg}$ was the most potent, the dose of $0.3 \mathrm{mg} / \mathrm{kg}$ was the least active, while the effect of 1 and $10 \mathrm{mg} / \mathrm{kg}$ doses was similar and weaker in comparison to the effect of a dose of $3 \mathrm{mg} / \mathrm{kg}$ (Fig. 1a). Repeated measures ANOVA showed a significant effect of treatment groups $\left(F_{4,25}=440, P<0.0001\right)$, sampling period $\left(F_{11,275}=27, P<0.0001\right)$, and the interaction between treatment groups and sampling period $\left(F_{44,275}=9.6, P<0.0001\right)$.

The middle 25I-NBOMe dose of $3 \mathrm{mg} / \mathrm{kg}$ induced the strongest increase in the extracellular 5-HT level in the frontal cortex (Fig. 1b). The effect of 1 and $10 \mathrm{mg} / \mathrm{kg}$ was weaker but significant in comparison with control group while the dose of $0.3 \mathrm{mg} / \mathrm{kg}$ was inactive (Fig. 1b). Repeated measures ANOVA showed a significant effect of treatment groups $\left(F_{4,25}=659, P<0.0001\right)$, sampling period $\left(F_{11,103}=96\right.$, $P<0.0001)$, and the interaction between treatment groups $\left(F_{44,275}=38, P<0.0001\right)$.

The extracellular glutamate level was not changed by the dose of $0.3 \mathrm{mg} / \mathrm{kg}$, but was increased more potently by 1 and $10 \mathrm{mg} / \mathrm{kg}$ doses than by the dose of $3 \mathrm{mg} / \mathrm{kg}$ (Fig. 1c). Repeated measures ANOVA showed a significant effect of treatment groups $\left(F_{4,25}=174, P<0.0001\right)$, sampling period $\left(F_{11,275}=30, P<0.0001\right)$, and the interaction between treatment groups $\left(F_{44,275}=41, P<0.0001\right)$.

The total effects expressed as AUC shown in Fig. 2a reflect the responses to 25I-NBOMe with respect to cortical DA, 5HT, and glutamate release presented as time-course curves. The total effect of a 25I-NBOMe middle dose of $3 \mathrm{mg} / \mathrm{kg}$ was the most potent on DA and 5-HT release, whereas the dose of $0.3 \mathrm{mg} / \mathrm{kg}$ slightly but significantly increased DA release, but did not affect 5-HT release. Glutamate release was nearly equally increased by doses of 1 and $10 \mathrm{mg} / \mathrm{kg}$, the dose of 
Fig. 1 The effects of N-(2methoxybenzyl)-2,5-dimethoxy4-iodophenethylamine (25INBOMe) on extracellular levels of dopamine (DA), serotonin (5HT), and glutamate (GLU) measured in the rat frontal cortex. Panels $\mathbf{a}, \mathbf{b}$, and $\mathbf{c}$ show each timecourses. Values are the mean \pm standard error of the mean (SEM) ( $n=6$ per experimental groups). The time of drug injection is indicated with an arrow. The basal extracellular levels of DA were $2.22 \pm 0.21(n=18)$; for 5-HT, $0.88 \pm 0.07(n=18)$ in $\mathrm{pg} / 10 \mu \mathrm{L}$ : for GLU, $2.84 \pm 0.32(n=18)$ in ng/10 $\mu \mathrm{L}$; "a" $P<0.01$ vs. control group; "b" and "c" $P<0.01$ show significant difference vs. 3 and $0.3 \mathrm{mg} / \mathrm{kg} 25 \mathrm{I}-\mathrm{NBOMe}$, respectively (repeated measures ANOVA and Tukey's post hoc test)
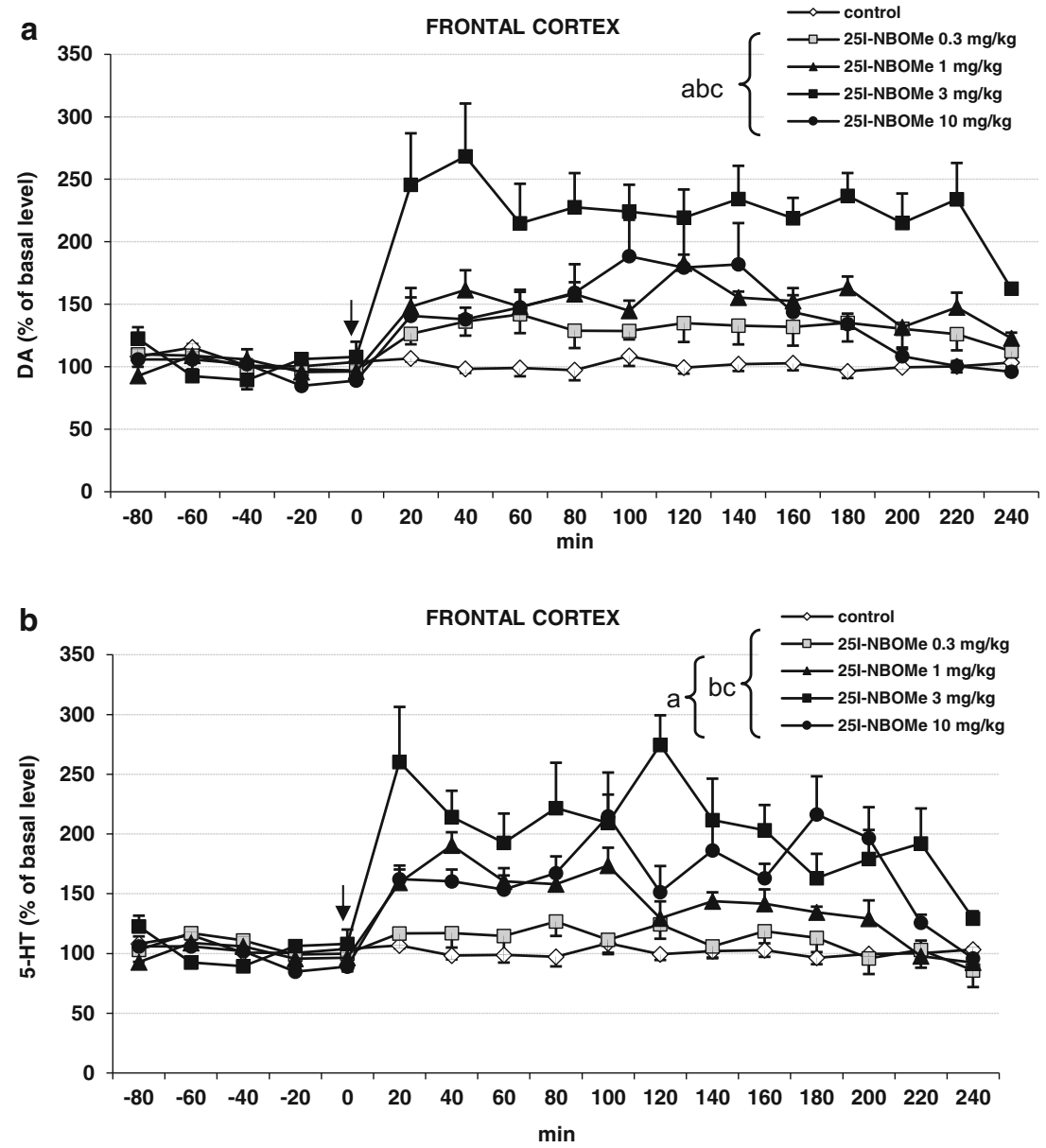

C

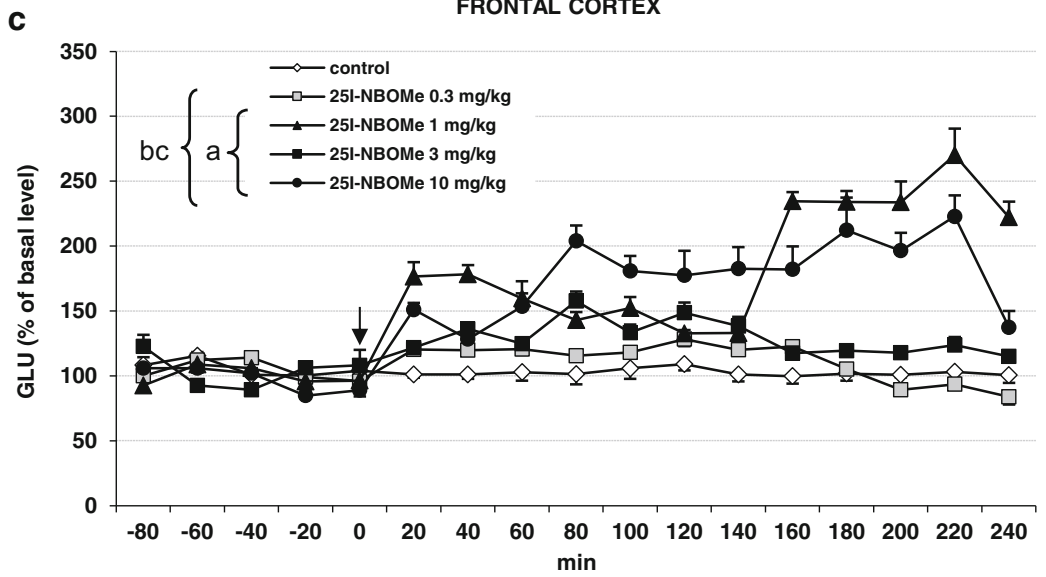

$3 \mathrm{mg} / \mathrm{kg}$ exerted the weakest but significant effect while the dose of $0.3 \mathrm{mg} / \mathrm{kg}$ was inactive in respect of glutamate release.

\section{The Effect of 25I-NBOMe on Head Twitches in Rats}

25I-NBOMe induced head twitches in rats, which were observed immediately after the administration. The middle dose of $3 \mathrm{mg} / \mathrm{kg}$ produced a weak effect, while the impact of the lowest dose of $0.3 \mathrm{mg} / \mathrm{kg}$ was significant but less potent in comparison to the middle dose. The response of 1 and $10 \mathrm{mg} / \mathrm{kg}$ doses was significantly stronger in comparison to the two lower doses (Fig. 2b).

The Effect of 25I-NBOMe on the Contents of DA, 5-HT, and their Metabolites in the Rat Frontal Cortex

25I-NBOMe did not affect significantly DA, DOPAC, and HVA tissue contents in the frontal cortex (Fig. 3a). However, 
Fig. 2 The effects of 25INBOMe on extracellular levels of DA, 5-HT, and GLU measured in the rat frontal cortex and headtwitch response induced by the drug. Panel a shows the total effects expressed as an area under the curve (AUC) of the percent of each basal level. Panel b shows the number of head twitches counted for 240 min starting immediately after injection. Values are the mean \pm standard error of the mean (SEM) $(n=6$ per experimental groups). "a" $P<0.01$ vs. control group; "b" and "c" $P<0.01$ show significant difference vs. 3 and $0.3 \mathrm{mg} / \mathrm{kg} 25 \mathrm{I}-$ NBOMe, respectively (one-way ANOVA and Tukey's post hoc test)
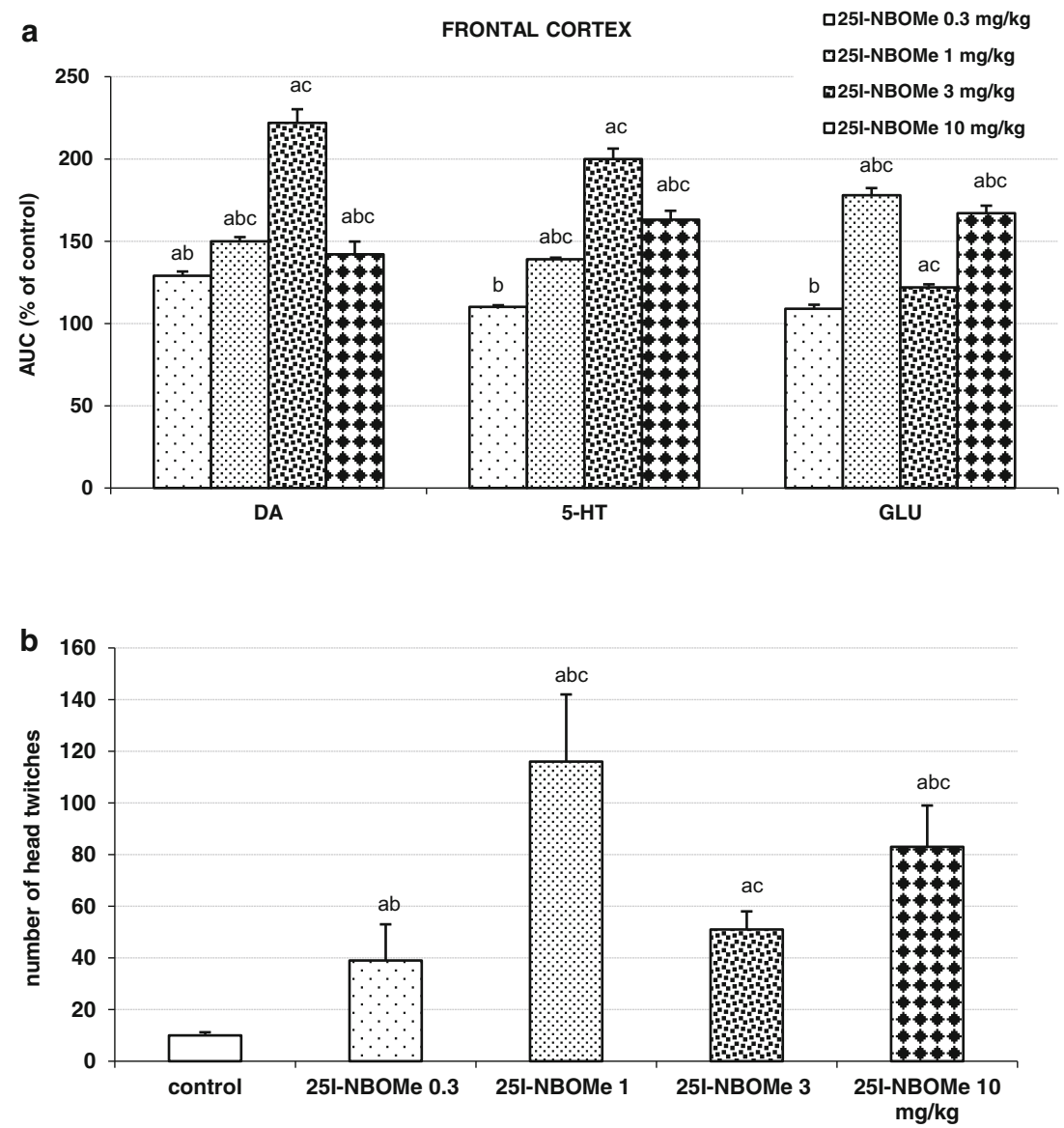

the contents of 5-HT and 5-HIAA were increased in an inverted $U$-shaped manner with the strongest effect of the $3 \mathrm{mg} / \mathrm{kg}$ dose (Fig. 3b).

\section{Discussion}

25I-NBOMe enhanced extracellular level of DA, 5-HT, and glutamate in the rat frontal cortex (Fig. 1a, b, c). It also increased cortical 5-HT and 5-HIAA tissue content (Fig. 3a, b). In addition, 25I-NBOMe produced hallucinogenic activity measured as head shake episodes (Fig. 2b).

The changes in extracellular levels of DA, 5-HT, and glutamate in the rat frontal cortex may be explained by agonist activity of $25 \mathrm{I}-\mathrm{NBOMe}$ at $5-\mathrm{HT}_{2 \mathrm{~A}}$ receptors for which this drug has sub-nanomolar affinity (Rickli et al. 2015). 5- $\mathrm{HT}_{2 \mathrm{~A}}$ receptors are highly expressed on glutamatergic pyramidal neurons and GABAergic basket and chandelier cells in layer $\mathrm{V}$ of the prefrontal cortex (Halberstadt 2015). The levels of 5$\mathrm{HT}_{2 \mathrm{~A}}$ receptor expression in neuronal cells vary in cortical regions. It is suggested that $50-60 \%$ of pyramidal neurons and only $20 \%$ of interneurons express $5-\mathrm{HT}_{2 \mathrm{~A}}$ receptors in the frontal cortex (Celada et al. 2013). However, it has been demonstrated that cortical pyramidal glutamatergic cells and
GABAergic interneurons also express $5-\mathrm{HT}_{1 \mathrm{~A}}$ receptors (Aznar et al. 2003; Santana et al. 2004). Furthermore, 5$\mathrm{HT}_{2 \mathrm{C}}$ receptor $\mathrm{mRNA}$ and protein are expressed in the frontal cortex, although with relatively weak intensity (Pompeiano et al. 1994). In layer V, these receptors are thought to be expressed postsynaptically in a subset of pyramidal neurons and GABAergic interneurons (Clement et al. 2000; Liu et al. 2007; Pompeiano et al. 1994). Thus, stimulation of 5-HT $2 \mathrm{~A}$ and $5-\mathrm{HT}_{1 \mathrm{~A}}$ receptors can be expected to have mixed effects, with some excitation due to local effects on pyramidal neurons as well as some inhibition due to stimulation of GABAergic interneurons. The available data also suggest that $5-\mathrm{HT}_{2 \mathrm{~A} / 2 \mathrm{C}}$ receptor stimulation by DOI leads to an overall activation on neuronal firing in the frontal cortex (Puig et al. 2003). Hallucinogens may regulate cortical GABA through activation of 5- $\mathrm{HT}_{2 \mathrm{~A}}$ receptors located on GABAergic interneurons (Zhou and Hablitz 1999). For instance, DOI administration through a microdialysis probe increased extracellular GABA in the rat prefrontal cortex (Abi-Saab et al. 1999).

25I-NBOMe, besides sub-nanomolar affinity for $5-\mathrm{HT}_{2 \mathrm{~A}}$ receptors, is potent in binding to $5-\mathrm{HT}_{2 \mathrm{C}}$ receptors and shows weaker but still high affinity for $5-\mathrm{HT}_{1 \mathrm{~A}}$ receptors (Rickli et al. 2015). The observed stimulatory effect of 25I-NBOMe on extracellular glutamate level in our study may be explained 
Fig. 3 The effects of 25INBOMe on tissue contents of DA, DOPAC, HVA, 5-HT, and 5HIAA in the rat frontal cortex measured 45 min after administration of the drug. Panels $\mathbf{a}$ and $\mathbf{b}$ show each percent change in comparison to control group and calculated from the absolute numbers given in nanograms/ milligrams of tissue presented in supplementary materials. Values are the mean \pm standard error of the mean (SEM) $(n=6$ per experimental groups). "a" $P<0.01$ vs. control group; "b" and "c" $P<0.01$ show significant difference vs. 3 and $0.3 \mathrm{mg} / \mathrm{kg} 25 \mathrm{I}-$ NBOMe, respectively (one-way ANOVA and Tukey's post hoc test)

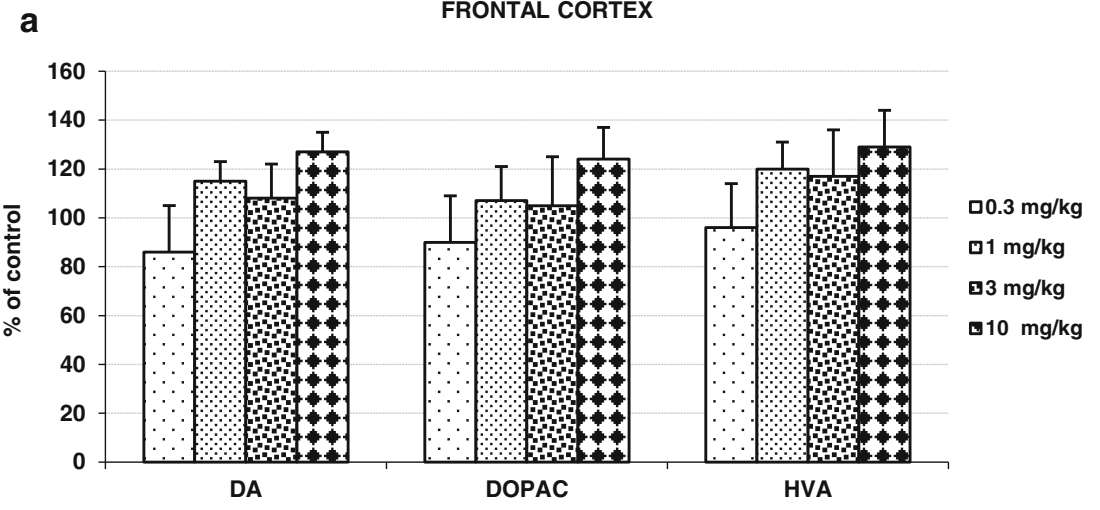

b

FRONTAL CORTEX

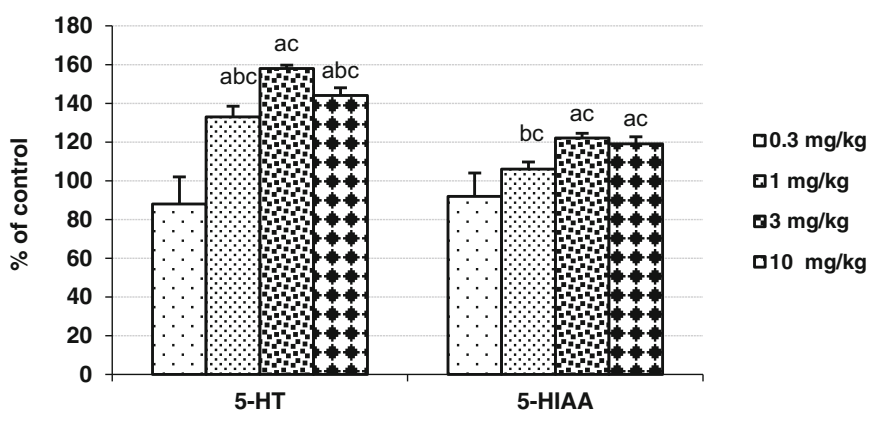

by mixed activity of the drug at serotonin receptors and seems to be dependent on the balance between the excitation of pyramidal cells and inhibition of GABAergic interneurons. The balance between excitatory and inhibitory response seems to be related with the 25I-NBOMe dose. The dose-response effect of 25I-NBOMe was $U$-shaped as the low $(1 \mathrm{mg} / \mathrm{kg})$ dose was similar in potency to the highest one $(10 \mathrm{mg} / \mathrm{kg})$ with respect to increasing glutamate release (Fig. 2a). The middle 25I-NBOMe dose of $3 \mathrm{mg} / \mathrm{kg}$ was the weakest in this effect while the dose of $0.3 \mathrm{mg} / \mathrm{kg}$ was inactive. Thus, the net effect on glutamate release may depend on the drug level in the brain and activation of different serotonin receptor subpopulations located in various cortical cells by 25I-NBOMe. In contrast to tryptamine hallucinogens, which besides being non-selective agonists of serotonin receptors are substrates for SERT (Nagai et al. 2007; Cozzi et al. 2009; Halberstadt and Geyer 2011), NBOMes are direct agonists of $5-\mathrm{HT}_{2}$ receptors. Therefore, the regulation of cortical glutamate extracellular level by 25INBOMe does not need necessarily be dependent on endogenous 5-HT level, as is shown in our study. Fantegrossi et al. (2010) reported biphasic dose-dependent effect of DOI on head-twitch behavior in mice. Those authors suggest that interaction of distinct serotonin receptors generates biphasic nature of the HTR response. It is possible that agonist 5- $\mathrm{HT}_{2 \mathrm{~A}}$ receptor activity of 25I-NBOMe at the dose of $1 \mathrm{mg} / \mathrm{kg}$ stimulates both glutamate release and head-twitch behavior, whereas the inhibition of both effects observed at the dose of $3 \mathrm{mg} / \mathrm{kg}$ may result from a competing agonist activation of 5$\mathrm{HT}_{2 \mathrm{C}}$ receptors. Wet dog shakes (WDS) produced by NBOMe compounds in Sprague-Dawley rats were suppressed by higher doses of these drugs providing evidence that $5-\mathrm{HT}_{2 \mathrm{C}}$ receptor stimulation can inhibit $5-\mathrm{HT}_{2 \mathrm{~A}}$-mediated WDS (Elmore et al. 2018; Vickers et al. 2001). Interestingly, increasing the $25 \mathrm{I}-\mathrm{NBOMe}$ dose to $10 \mathrm{mg} / \mathrm{kg}$ resulted in enhancement of extracellular glutamate to the nearly similar level as that produced by the dose of $1 \mathrm{mg} / \mathrm{kg}$. WDS response also increased but was weaker in comparison to the response to $1 \mathrm{mg} / \mathrm{kg}$ dose. The reasons for the increase in both effects are not apparent from the in vitro data. The potency of NBOMes at other receptors (adrenergic, dopaminergic) or monoamine transporters is low (Rickli et al. 2015). However, 25I-NBOMe exhibits in vitro affinity for $5-\mathrm{HT}_{1 \mathrm{~A}}$ receptors with $K_{i}=1800 \mathrm{nM}$ (Rickli et al. 2015). 5-HT $1 \mathrm{~A}$ receptors are expressed on cortical GABAergic interneurons (Aznar et al. 2003; Santana et al. 2004). Hence, activation of $5-\mathrm{HT}_{1 \mathrm{~A}}$ receptors by high concentration of the drug may reveal inhibitory influence of GABA interneurons facilitating effect of $5-\mathrm{HT}_{2 \mathrm{~A}}$ receptors on glutamate release and WDS response.

Cortical pyramidal neurons send long-distance axons to subcortical regions forming loops by which they modulate dopaminergic and serotonergic transmission (Di Matteo et 
al. 2008; Soiza-Reilly and Commons 2011). 5- $\mathrm{HT}_{2 \mathrm{~A}}$ receptors on pyramidal neurons may stimulate directly DA cells in the ventral tegmental area (VTA) or 5-HT cells in the raphe nuclei. This action may be modulated by $5-\mathrm{HT}_{1 \mathrm{~A}}$ or $5-\mathrm{HT}_{2 \mathrm{C}}$ receptors localized on GABAergic interneurons not only in the frontal cortex but also in the VTA or raphe cells. Thus, GABAergic interneurons provide a link between several classes of serotonin receptors. Concomitant activation the $5-\mathrm{HT}_{2 \mathrm{~A}}$ or $5-\mathrm{HT}_{2 \mathrm{C}}$ receptors releases GABA which inhibits mesocortical DA cells as well as 5-HT neurons. In addition, activation of 5$\mathrm{HT}_{1 \mathrm{~A}}$ autoreceptors triggers directly the inhibition of serotonin neuron transmission (Di Matteo et al 2008; Soiza-Reilly and Commons 2011).

As observed in our study, activation of serotonin receptors by 25I-NBOMe caused an increase in DA and 5-HT release in the frontal cortex (Fig. 1a, b). The dose-response effect showed an inverted " $U$ " shape with a middle dose of $3 \mathrm{mg} / \mathrm{kg}$ being the most potent. Thus, the pattern of the effect exerted by 25I-NBOMe on DA and 5-HT release did not reflect the changes in cortical glutamate release produced by the drug. It is likely that a weaker stimulation of descending pathways by this dose exerted a weaker impact on GABAergic interneurons to inhibit DA and 5-HT cells in the VTA or raphe nuclei. Subsequently, more neurotransmitters were released from neuronal terminals in the frontal cortex. This effect may be modulated by direct action of 25I-NBOMe via $5-\mathrm{HT}_{2 \mathrm{~A}}$ receptors on $5-\mathrm{HT}$ cells or $5-\mathrm{HT}_{2 \mathrm{~A}}$ and $5-\mathrm{HT}_{2 \mathrm{C}}$ receptors on GABAergic interneurons (Di Matteo et al 2008). At higher dose of $10 \mathrm{mg} / \mathrm{kg}$ by direct action via $5-\mathrm{HT}_{1 \mathrm{~A}}$ autoreceptors 25I-NBOMe may suppress raphe cells firing causing the observed decrease in 5-HT release from cortical nerve terminals (Haigler and Aghajanian 1973). The inverted "U" shape manner of the neurotransmitter release was mimicked by the measured 5-HT and 5-HIAA content in the frontal cortex (Fig. 3b). Similarly, direct modulation of VTA dopaminergic neurons through activation of $5-\mathrm{HT}_{2 \mathrm{~A}}$ receptors by 25I-NBOMe may affect DA release from cortical terminals (Cornea-Hébert et al. 1999; Nocjar et al. 2002; Pehek et al. 2001). Some $5-\mathrm{HT}_{2 \mathrm{C}}$ receptors situated on GABAergic interneurons in the VTA may suppress triggering of DA release by higher doses of the drug (Di Matteo et al. 2008; Nocjar et al. 2002; Pehek et al. 2001). 25I-NBOMe did not enhance significantly the contents of DA and its metabolites and only a tendency towards the increase was observed (Fig. 3a). Thus, the pattern of changes in DA release does not reflect the changes in the contents of DA and its metabolites. It may be hypothesized that the lack of parallelism between changes in release and tissue DA content may result from different regulation of neurotransmitter synthesis and release. DA synthesis may depend more on excitatory projections from the cortex reaching cell bodies in the VTA while synaptic DA release may be modulated by local tonic influences via serotonin receptors on neuronal terminals.
25I-NBOMe displayed hallucinogenic activity as shown by the number of head shakes measured during $4 \mathrm{~h}$ after drug administration. Interestingly, the number of shakes followed the pattern of changes in glutamate release with the middle dose of $3 \mathrm{mg} / \mathrm{kg}$ being the weakest in this test (Fig. 2b). This is the evidence that hallucinogenic activity of $25 \mathrm{I}-\mathrm{NBOMe}$ seems to be associated with glutamate release in the cortex and may be mediated via $5-\mathrm{HT}_{2 \mathrm{~A}}$ receptors. Our data are the first to connect hallucinogenic-like behavior in rodents with glutamate release in the frontal cortex after administration of this sub-class of hallucinogens. So far, there are only two studies showing an increase in cortical glutamate release by LSD and DOM (Muschamp et al. 2004) or DOI (Scruggs et al. 2003). Still, HTR was shown in mice (Halberstadt and Geyer 2014) and in Sprague-Dawley rats (Elmore et al. 2018).

Taken together, the results of our study expand our knowledge on a new very potent group of hallucinogens represented by 25I-NBOMe. The obtained data show that 25I-NBOMe affects DA, 5-HT, and glutamatergic neurotransmission. The observed hallucinogenic activity of 25I-NBOMe may be associated with glutamate release in the frontal cortex.

Funding Information Supported by the National Science Centre, Kraków, Poland (Grant No 2016/21/B/NZ7/01131). MH is supported by the InterDokMed project No POWR.03.02.00-00-I013/1.

\section{Compliance with Ethical Standards}

Conflict of Interest The authors declare that they have no conflict of interest.

Ethical Approval The use of adult male rats for the experiments was approved by the Local Ethical Commission for Experimentations on Animals in Kraków. This article does not contain any studies with human participants.

Open Access This article is distributed under the terms of the Creative Commons Attribution 4.0 International License (http:// creativecommons.org/licenses/by/4.0/), which permits unrestricted use, distribution, and reproduction in any medium, provided you give appropriate credit to the original author(s) and the source, provide a link to the Creative Commons license, and indicate if changes were made.

\section{References}

Abi-Saab WM, Bubser M, Roth RH, Deutch AY (1999) 5-HT2 receptor regulation of extracellular GABA levels in the prefrontal cortex. Neuropsychopharmacology 20:96. https://doi.org/10.1016/S0893133X(98)00046-3

Abramson H, Jarvik M, Govin M, Hirsch M (1956) Lysergic acid diethylamide (LSD-25): XVIII. Tolerance development and is relationship to a theory of psychosis. J Psychol 41:81-105. https://doi. org/10.1080/00223980.1955.9916156

Aghajanian GK, Haigler HJ (1975) Hallucinogenic indoleamines: oreferential action upon presynaptic serotonin receptors. Psychopharmacol Commun 1:619-629 
Aghajanian GK, Marek GJ (1997) Serotonin induces excitatory postsynaptic potentials in apical dendrites of neocortical pyramidal cells. Neuropharmacology 36:589-599. https://doi.org/10.1016/S00283908(97)00051-8

Al-Imam A, Abdul Majeed BA (2017) NBOMe compounds: systematic review and data crunching of the surface web. Global J Health Sci 9: 126-139. https://doi.org/10.5539/gjhs.v9n11p126

Andreasen MF, Telving R, Rosendal I, Eg MB, Hasselstrom JB, Andersen LV (2015) A fatal poisoning involving 25C-NBOMe. Forensic Sci Int 251:1-8. https://doi.org/10.1016/j.forsciint.2015. 03.012

Angrist B, Rotrosen J, Gershon S (1974) Assessment of tolerance to the hallucinogenic effects of DOM. Psychopharmacologia 36:203-207. https://doi.org/10.1007/BF00421802

Aznar S, Qian Z, Shah R, Rahbek B, Knudsen GM (2003) The 5-HT1A serotonin receptor is located on calbindin- and parvalbumincontaining neurons in the rat brain. Brain Res 959:58-76. https:// doi.org/10.1016/S0006-8993(02)03727-7

Baumann MH, Glennon RA, Wiley JL (2017) Neuropharmacology of new psychoactive substances. Curr Top Behav Neurosci 32:93117. https://doi.org/10.1007/7854_2016_53

Braden MR, Parrish JC, Naylor JC, Nichols DE (2006) Molecular interaction of serotonin 5-HT2A receptor residues Phe339(6.51) and Phe340(6.52) with superpotent N-benzyl phenethylamine agonists. Mol Pharmacol 70:1956-1964. https://doi.org/10.1124/mol.106. 028720

Canal CE, Olaghere de Silva UB, Gresh PJ, Watt EE, Sanders-Bush E, Airey DC (2010) The serotonin 2 C receptor potently modulates the head-twitch response in mice induced by a phenylethylamine hallucinogen. Psychopharmacology (Berl) 209:163-174. https://doi.org/ 10.1007/s00213-010-1784-0

Celada P, Puig MV, Artigas F (2013) Serotonin modulation of cortical neurons and networks. Front Integr Neurosci 7:1-20. https://doi.org/ 10.3389/fnint.2013.00025

Clement DA, Punhani T, Duxon MS, Blackburn TP, Fone KC (2000) Immunohistochemical localization of the 5-HT2C receptor protein in the rat CNS. Neuropharmacology 39:123-132. https://doi.org/10. 1016/S0028-3908(99)00086-6

Cornea-Hébert V, Riad M, Wu C, Singh SK, Descarries L (1999) Cellular and subcellular distribution of the serotonin 5-HT2A receptor in the central nervous system of adult rat. J Comp Neurol 409:187-209. https://doi.org/10.1002/(SICI)1096-9861(19990628)409:2<187:: AID-CNE2>3.0.CO;2-P

Cozzi NV, Gopalakrishnan A, Anderson LL, Feih JT, Shulgin AT, Daley PF, Ruoho AE (2009) Dimethyltyptamine and other hallucinogenic tryptamines exhibit substrate behavior at the serotonin uptake transporter and the vesicle monoamine transporter. J Neural Transm 116: 1591-1599. https://doi.org/10.1007/s00702-009-0308

Di Mateo V, Di Giovanni G, Pierucci M, Esposito E (2008) Serotonin control of central dopaminergic function: focus in in vivo microdialysis studies. Prog Brain Res 172:7-44. https://doi.org/10.1016/ S0079-6123(08)00902-3

Elmore JS, Decker AM, Sulima A, Rice KC, Partilla JS, Blough BE, Baumann MH (2018) Comparative neuropharmacology of N-(2methoxybenzyl)-2,5-dimethoxyphenethylamine (NBOMe) hallucinogens and their $2 \mathrm{C}$ counterparts in male rats. Neuropharmacology 142:240-250. https://doi.org/10.1016/j. neuropharm.2018.02.033

EMCDDA (2018) European drug report. Trends and developments. http:/www.emcdda.europa.eu/system/files/publications/8585/ 20181816_TDAT18001ENN_PDF.pdf. Accessed 15 Oct 2018

Fantegrossi WE, Simoneau J, Cohen MS, Zimmerman SM, Henson CM, Rice KC, Woods JH (2010) Interaction of 5-HT2A and 5-HT2C receptors in R(-)-2,5-Dimethoxy-4-iodoamphetamine-elicited head twitch behavior in mice. J Pharmacol Exp Ther 335:728-734. https://doi.org/10.1124/jpet.110.172247
Gatch MB, Dolan SB, Forster MJ (2017) Locomotor and discriminative stimulus effects of four novel hallucinogens in rodents. Behav Pharmacol 28:375-385. https://doi.org/10.1097/FBP. 0000000000000309

Gee P, Schep LJ, Jensen BP, Moore G, Barrington S (2016) Case series: toxicity from 25B-NBOMe - a cluster of N-bomb cases. Clin Toxicol (Phila) 54:141-146. https://doi.org/10.3109/15563650. 2015.1115056

Glennon RA, Titeler M, McKenney JD (1984) Evidence for 5-HT 2 involvement in the mechanism of action of hallucinogenic agents. Life Sci 35:2505-2511. https://doi.org/10.1016/0024-3205(84)90436-3

Haigler HJ, Aghajanian GK (1973) Mescaline and LSD: direct and indirect effects on serotonin-containing neurons in brain. Eur $\mathrm{J}$ Pharmacol 21:53-60. https://doi.org/10.1016/0014-2999(73) 90206-9

Halberstadt AL (2015) Recent advances in the neuropsychopharmacology of serotonergic hallucinogens. Behav Brain Res 277:99-120. https:// doi.org/10.1016/j.bbr.2014.07.016

Halberstadt AL (2017) Pharmacology and toxicology of Nbenzylphenethylamine ("NBOMe") hallucinogens. Curr Top Behav Neurosci 32:283-311. https://doi.org/10.1016/j.cub.2016. 12.058

Halberstadt AL, Geyer MA (2011) Multiple receptors contribute to the behavioral effects of indoleamine hallucinogens. Neuropharmacology 61: 364-381. https://doi.org/10.1016/j.neuropharm.2011.01017

Halberstadt AL, Geyer MA (2014) Effects of the hallucinogen 2,5dimethoxy-4-iodophenethylamine (2C-I) and superpotent N-benzyl derivatives on the head twitch response. Neuropharmacology 77 : 200-207. https://doi.org/10.1016/j.neuropharm.2013.08.025

Halberstadt AL, van der Heijden I, Ruderman MA, Risbrough VB, Gingrich JA, Geyer MA, Powell SB (2009) 5-HT2A and 5-HT2C receptors exert opposing effects on locomotor activity in mice. Neuropsychopharmacology 34:1958-1967. https://doi.org/10. 1038/npp.2009.29

Hill SL, Thomas SHL (2011) Clinical toxicology of newer recreational drugs. Clin Toxicol (Phila) 49:705-719. https://doi.org/10.3109/ 15563650.2011.615318

Klein LM, Cozzi NV, Daley PF, Brandt SD, Halberstadt AL (2018) Receptor binding profiles and behavioral pharmacology of ringsubstituted $N, N$-diallyltryptamine analogs. Neuropharmaology 142:231-239. https://doi.org/10.1016/j.neuropharm.2018.02.028

Kueppers VB, Cooke CT (2015) 25I-NBOMe related death in Australia: a case report. Forensic Sci Int 249:15-18. https://doi.org/10.1016/j. forsciint.2015.02.010

Kyriakou C, Marinelli E, Frati P, Santurro A, Afxentiou M, Zaami S, Busardo FP (2015) NBOMe: new potent hallucinogens - pharmacology, analytical methods, toxicities, fatalities: a review. Eur Rev Med Pharmacol Sci 19:3270-3281

Liu S, Bubar MJ, Lanfranco MF, Hillman GR, Cunningham KA (2007) Serotonin $2 \mathrm{C}$ receptor localization in GABA neurons of the rat medial prefrontal cortex: implications for understanding the neurobiology of addiction. Neuroscience 146:1677-1688. https://doi.org/10. 1016/j.neuroscience.2007.02.064

Martín-Ruiz R, Puig MV, Celada P, Shapiro DA, Roth BL, Mengod G, Artigas F (2001) Control of serotonergic function in medial prefrontal cortex by serotonin-2A receptors through a glutamate-dependent mechanism. J Neurosci 21:9856-9866. https://doi.org/10.1523/ JNEUROSCI.21-24-09856.2001

Muschamp JW, Regina MJ, Hull EM, Winter JC, Rabin RA (2004) Lysergic acid diethylamide and [-]-2,5-dimethoxy-4methylamphetamine increase extracellular glutamate in rat prefrontal cortex. Brain Res 1023:134-140. https://doi.org/10.1016/j. brainres.2004.07.044

Nagai F, Nonaka R, Satoh Hisashi Kamimura K (2007) The effects of non-medically used psychoactive drugs on monoamine 
neurotransmission in rat brain. Eur J Pharmacol 559:132-137. https://doi.org/10.1016/j.ejphar.2006.11.075

Nichols DE (2004) Hallucinogens. Pharmacol Ther 101:131-181. https:// doi.org/10.1016/j.pharmthera.2003.11.002

Nichols DE (2012) Structure-activity relationships of serotonin 5- $\mathrm{HT}_{2 \mathrm{~A}}$ agonists. WIREs Membr Transp Signal 1:559-579. https://doi.org/ $10.1002 /$ wmts. 42

Nichols DE (2016) Psychedelics. Pharmacol Rev 68:264-355. https:// doi.org/10.1124/pr.115.011478

Nichols DE, Sassano MF, Halberstadt AL, Klein LM, Brandt SD, Elliott SP, Fiedler WJ (2015) N-Benzyl-5-methoxytryptamines as potent serotonin 5-HT2 receptor family agonists and comparison with series of phenethylamine analogues. ACS Chem Neurosci 6:11651175. https://doi.org/10.1021/cn500292d

Nikolaou P, Papoutsis I, Stefanidou M, Spiliopoulou C, Athanaselis S (2015) 2C-I-NBOMe, an "N-bomb" that kills with "Smiles". Toxicological and legislative aspects. Drug Chem Toxicol 38:113119. https://doi.org/10.3109/01480545.2014.911882

Nocjar C, Roth BL, Pehek EA (2002) Localization of 5-HT(2A) receptors on dopamine cells in subnuclei of the midbrain A10 cell group. Neuroscience 111:163-176. https://doi.org/10.1016/S03064522(01)00593-0

Noworyta-Sokołowska K, Kamińska K, Kreiner G, Rogóż Z, Gołembiowska K (2016) Neurotoxic effects of 5-MeO-DIPT: a psychoactive tryptamine derivative in rats. Neurotox Res 30:606-619. https://doi.org/10.1007/s12640-016-9654-0

Noworyta-Sokołowska K, Kamińska K, Rzemieniec J, Wnuk A, Wojcieszak J, Górska AM, Kreiner G, Kajta M, Gołembiowska K (2019) Effects of exposure to 5-MeO-DIPT during adolescence on brain neurotransmission and neurotoxicity in adult rats. Forensic Toxicol 37:45-58. https://doi.org/10.1007/s11419-018-0433-x

Paxinos G, Watson C (1998) The rat brain in stereotaxic coordinates. Academic Press, Cambridge

Pehek EA, McFarlane HG, Maguschak K, Price B, Pluto CP (2001) M100,907, a selective 5-HT(2A) antagonist, attenuates dopamine release in the rat medial prefrontal cortex. Brain Res 888:51-59. https://doi.org/10.1016/S0006-8993(00)03004-3

Pierce PA, Peroutka SJ (1989) Hallucinogenic drug interactions with neurotransmitter receptor binding sites in human cortex. Psychopharmacology 97:118-122. https://doi.org/10.1007/ BF00443425

Poklis JL, Raso SA, Alford KN, Poklis A, Peace MR (2015) Analysis of $25 \mathrm{I}-\mathrm{NBOMe}, 25 \mathrm{~B}-\mathrm{NBOMe}, 25 \mathrm{C}-\mathrm{NBOMe}$ and other dimethoxyphenyl-N-[(2-methoxyphenyl) methyl]ethanamine derivatives on blotter paper. J Anal Toxicol 39:617-623. https://doi.org/ 10.1093/jat/bkv073

Pompeiano M, Palacios JM, Mengod G (1994) Distribution of the serotonin 5-HT2A receptor family mRNAs: comparison between 5HT2A and 5-HT2C receptors. Brain Res Mol Brain Res 23:163178. https://doi.org/10.1016/0169-328X(94)90223-2

Puig MV, Celada P, Diaz-Matix L, Artigas F (2003) In vivo modulation of the activity of pyramidal neurons in the rat medial prefrontal cortex by 5-HT2A receptors: relationship to thalamocortical afferents. Cereb Cortex 13:870-882. https://doi.org/10.1093/cencor/13.8.870

Rickli A, Luethi D, Reinisch J, Buchy D, Hoener MC, Liechti ME (2015) Receptor interaction profiles of novel N-2-methoxybenzyl (NBOMe) derivatives of 2,5-dimethoxy-substituted phenethylamines $(2 \mathrm{C}$ drugs). Neuropharmacology 99:546-553. https://doi.org/10.1016/j. neuropharm.2015.08.034

Rose SR, Poklis JL, Poklis A (2013) A case of 25I-NBOMe (25-I) intoxication: a new potent 5-HT2A agonist designer drug. Clin Toxicol
(Phila) 51:174-177. https://doi.org/10.3109/15563650.2013. 772191

Rowley HL, Martin KF, Marsden CA (1995) Determination of in vivo amino acid neurotransmitters by high-performance liquid chromatography with $o$-phthalaldehyde-sulphite derivatization. J Neurosci Methods 57:93-99. https://doi.org/10.1016/0165-0270(94)00132-z

Santana N, Bortolozzi A, Serrats J, Mengod G, Artigas F (2004) Expression of serotonin $1 \mathrm{~A}$ and serotonin $2 \mathrm{~A}$ receptors in pyramidal and GABAergic neurons of the rat prefrontal cortex. Cereb Cortex 14:1100-1109. https://doi.org/10.1093/cencor/bhh070

Schultes RE, Hofmann A, Rätsch C (1998) Plants of the gods: their sacred, healing, and hallucinogenic powers. Healing Art Press, Rochester, pp 1-208. https://doi.org/10.2307/2806799

Scruggs JL, Schmidt D, Deutch AY (2003) The hallucinogen 1-[2,5dimethoxy-4-iodophenyl]-2-aminopropane (DOI) increases cortical extracellular glutamate levels in rats. Neurosci Lett 346:137-140. https://doi.org/10.1016/S0304-3940(03)00547-0

Shanks KG, Sozio T, Behonick GS (2015) Fatal intoxications with 25BNBOMe and 25I-NBOMe in Indiana during 2014. J Anal Toxicol 39:602-606. https://doi.org/10.1093/jat/bkv058

Sipes TA, Geyer MA (1995) DOI disruption of prepulse inhibition of startle in the rat is mediated by $5-\mathrm{HT}(2 \mathrm{~A})$ and not by $5-\mathrm{HT}(2 \mathrm{C})$ receptors. Behav Pharmacol 6:839-842. https://doi.org/10.1097/ 00008877-199512000-00010

Soiza-Reilly M, Commons KG (2011) Glutamatergic drive of the dorsal raphe nucleus. J Chem Neuroanat 41:247-255. https://doi.org/10. 1016/j.jchemneu.2011.04.004

Suzuki J, Dekker MA, Valenti ES, Arbelo Cruz FA, Correa AM, Poklis JL, Poklis A (2015) Toxicities associated with NBOMe ingestion, a novel class of potent hallucinogens: a review of the literature. Psychosomatics 56:129-139. https://doi.org/10.1016/j.psym.2014. 11.002

UNODC Report (2013). World drug report. United Nations publication. https://www.unodc.org/wdr2017/field/Booklet_4_ATSNPS.pdf . Sales No. E. 13.XI.6 (Vol. 2013). https://doi.org/10.1002/yd.20002

Vickers SP, Easton N, Malcolm CS, Allen NH, Porter RH, Bickerdike MJ, Kennett GA (2001) Modulation of 5-HT(2A) receptor-mediated head-twitch behaviour in the rat by $5-\mathrm{HT}(2 \mathrm{C})$ receptor agonists. Pharmacol Biochem Behav 69:643-652. https://doi.org/10.1016/ S0091-3057(01)00552-4

Walterscheid JP, Phillips GT, Lopez AE, Gonsoulin ML, Chen HH, Sanchez LA (2014) Pathological findings in 2 cases of fatal 25INBOMe toxicity. Am J Forensic Med Pathol 35:20-25. https://doi. org/10.1097/PAF.0000000000000082

Wing LL, Tapson GS, Geyer MA (1990) 5HT-2 mediation of acute behavioral effects of hallucinogens in rats. Psychopharmacology 100: 417-425. https://doi.org/10.1007/bf02244617

Wolbach AB, Isbell H, Miner EJ (1962) Cross tolerance between mescaline and LSD-25 with a comparison of the mescaline and LSD reactions. Psychopharmacologia 14:1-14. https://doi.org/10.1007/ bf00413101

Zhou FM, Hablitz JJ (1999) Activation of serotonin receptors modulates synaptic transmission in rat cerebral cortex. J Neurophysiol 82: 2989-2999. https://doi.org/10.1152/jn.1999.82.6.2989

Zuba D, Sekuła K, Buczek A (2013) 25C-NBOMe - new potent hallucinogenic substance identified on the drug market. Forensic Sci Int 227:7-14. https://doi.org/10.1016/j.forsciint.2012.08.027

Publisher's Note Springer Nature remains neutral with regard to jurisdictional claims in published maps and institutional affiliations. 